Article

\title{
A Core National Security Interest: Framing Atrocities Prevention
}

\author{
Matthew Levinger \\ Elliott School of International Affairs, George Washington University, Washington, DC 20052, USA; \\ E-Mail: mlevinger@email.gwu.edu
}

Submitted: 22 May 2015 | In Revised Form: 23 July 2015 | Accepted: 27 July 2015 |

Published: 26 November 2015

\begin{abstract}
This essay analyzes President Barack Obama's communication strategies in his speeches and presidential statements concerning threats of mass atrocities in Libya, Syria, and Iraq from 2011 through 2015. It examines how he has used three rhetorical "frames" to explain events in these countries and to advocate specific U.S. policy responses: the "legalistic" (or "liberal internationalist"), the "moralistic," and the "security" frame. Obama utilized primarily the legalistic frame to justify U.S. military intervention in Libya in 2011, and he relied mainly on the security frame (focusing on terrorist threats against U.S. nationals) to justify the deployment of U.S. military forces against ISIL in Iraq and Syria in 2014-2015. Obama's rhetorical framing of the violence perpetrated by the Syrian regime of Bashar al-Assad since 2011 has been less consistent. Hardly ever in these speeches did Obama suggest that mass atrocities per se constituted a threat to U.S. national security-despite the declaration in Obama's 2011 Presidential Study Directive on Mass Atrocities that "preventing mass atrocities and genocide is a core national security interest" of the United States. Utilizing an approach to linguistic analysis developed by Roman Jakobson, the paper shows how Obama has employed rhetorical devices that emphasize the boundaries between the "in-group" of the American national community and the "outgroups" in other countries who are threatened by mass atrocities. Because members of an in-group are typically depicted as warranting greater concern than members of out-groups, Obama's assignment of victimized communities to out-group status has effectively justified inaction by the U.S. government in the face of genocidal violence.
\end{abstract}

\section{Keywords}

Barack Obama; communication; genocide prevention; mass atrocities; Libya; Syria; Islamic State; speech; US President

\section{Issue}

This article is part of the special issue "Mass Atrocity Prevention", edited by Professor Karen E. Smith (London School of Economics and Political Science, UK).

(C) 2015 by the author; licensee Cogitatio (Lisbon, Portugal). This article is licensed under a Creative Commons Attribution 4.0 International License (CC BY).

\section{Introduction}

The opening paragraph of the Albright-Cohen Genocide Prevention Task Force report, published a month after U.S. President Barack Obama's election in 2008, described genocide as a crime that "threatens not only our values, but our national interests" (Albright \& Cohen, 2008, p. ix). Three years later, President Obama reiterated this claim in the opening line of his Presidential Study Directive on Mass Atrocities (PSD 10) issued in August 2011: "Preventing mass atrocities and genocide is a core national security interest and a core mor- al responsibility of the United States" (Obama, 2011f).

Many observers believe that the Obama administration's record in fulfilling the promise of this presidential directive has been mixed. On the positive side of the ledger, the U.S. government has put in place mechanisms to facilitate more timely and comprehensive responses to threats of genocide and mass atrocities around the world. For example, in 2013 the U.S. intelligence community issued its first National Intelligence Estimate on "Global Risks of Mass Atrocities and Prospects for International Response," and the interagency Atrocity Prevention Board (APB) has convened on a 
monthly basis since 2012 in order to recommend coordinated policy responses to emerging threats.

Not only has the establishment of the APB provided a standing forum for interagency deliberation concerning threats of genocide and mass atrocities, it has also stimulated increased attention to this issue within individual U.S. government agencies. For example, in the Quadrennial Diplomacy and Development Review issued in April 2015, the U.S. State Department flagged the issue of "preventing and mitigating conflict and violent extremism" as the first of four institutional Strategic Priorities. It identified atrocities prevention as one of five "lines of effort" to achieve this objective (U.S. Department of State, 2015, p. 24). Likewise, the Department of Defense issued guidance on Mass Atrocities Response Operations in its 2012 Joint Publication 3-07.03 on Peace Operations (DOD, 2012, Appendix B), and the U.S. Agency for International for International Development (USAID) has published an operational field guide entitled Helping Prevent Mass Atrocities (2015).

This new doctrine and administrative machinery for atrocities prevention within the U.S. government have facilitated more robust and sustained attention to civil strife in countries of otherwise peripheral interest to senior U.S. policymakers, including Burma, Kenya, Burundi, the Central African Republic, and South Sudan. But the APB has achieved little traction in influencing the administration's policy priorities in regions of more central concern to U.S. national security, such as North Africa, Syria, and Iraq. In the words of Jim Finkel (2014), a former senior U.S. government official who was a key participant in the APB,

The Board continues to be viewed skeptically-and occasionally even hostilely-from some quarters within the national security establishment....Despite regular assurances from senior levels within the White House that the President feels strongly about the atrocity prevention initiative he endorsed, there have been persistent signs that parts of the bureaucracy remain skeptical of the policy and the President's "real" intent. This initial skepticism has only grown as the debates over Iraq, Afghanistan, and Syria have unfolded (pp. 1, 27).

This essay will analyze President Obama's rhetorical framing of the atrocities prevention agenda. Through a close reading of fifteen presidential speeches and statements delivered between 2011 and 2015, I will examine how Obama has discussed potential or actual incidents of mass atrocities in Libya, Syria, and Iraq. In particular, I will explore how he has utilized three rhetorical "frames" to describe the violence in these countries and to prescribe the U.S. government's policy response:

- The legalistic (or liberal internationalist) frame, which depicts the violence as a violation of human rights and international law;

- The moralistic frame, which emphasizes the brutality of the perpetrators and the suffering of the victims; and

- The security frame, which stresses the potential threats that the violence poses to American citizens and the U.S. homeland.

In most of the speeches and presidential statements analyzed here, all three of these frames appeared to a greater or lesser extent, but one or two were typically dominant. For example, the legalistic frame dominated most of Obama's speeches concerning Libya in 20112012, whereas the security frame was overwhelmingly emphasized in most of his speeches regarding the Islamic State in Iraq and the Levant (ISIL) in 2014-2015. In Obama's speeches on Syria between 2011 and 2013, the pattern was less coherent: the President vacillated between describing the violence perpetrated by the Assad regime as a violation of international law, as a moral outrage, and as a threat to U.S. national security.

Although President Obama's speeches and statements during this period regularly employed a range of frames to discuss regions at risk of genocide or mass atrocities, virtually never-except in PSD 10 itself and in his April 2012 speech at the U.S. Holocaust Memorial Museum unveiling the Atrocity Prevention Board (Obama, 2012a)-did he depict mass atrocities per se as a threat to U.S. national security interests. Indeed, in his September 2013 speech to the UN General Assembly, the President pointedly excluded atrocities prevention from his list of "America's core interests" (Obama, 2013d). Based on the record of these public speeches, the nameless bureaucrats to whom Finkel alludes in his paper would appear justified in their skepticism about the "President's 'real' intent" concerning the atrocities prevention agenda.

The essay concludes that President Obama's inconsistent framing of the challenge of atrocities prevention has resulted in missed opportunities for advancing U.S. national interests. In a volatile era characterized by unconventional and asymmetric security threats, the U.S. government and its international partners confront challenges not only to their military power but also to the moral legitimacy of their authority. A key strategic objective of emerging adversaries such as the Islamic State is to undermine the legitimacy and credibility of the U.S. and its allies through the commission of mass atrocities and other acts of violence against civilian noncombatants (Cronin, 2012, 2015; Naji, 2004/2006). Although, in any given situation, U.S. leaders may labor under policy constraints that limit their capacity to take effective preventive action, it is essential to articulate a clear and consistent set of principles to inform and explain their decisions. Signaling a robust commitment to atrocities prevention- 
both through words and through deeds - is a critical component of the broader effort to reinforce the legitimacy of American power.

\section{Reframing the Strategic Narrative: Atrocities Prevention as a Security Interest}

In the 2003 study "A Problem from Hell": America and the Age of Genocide, Samantha Power presented a stinging critique of the U.S. government's passivity in the face of genocidal violence over the course of the twentieth century. Writing a decade before she herself became U.S. Ambassador to the United Nations, Power pointed out that "the United States has consistently refused to take risks in order to suppress genocide." Because "America's 'vital national interests' were not considered imperiled by mere genocide," she asserted, "senior U.S. officials did not give genocide the moral attention it warranted" (Power, 2003, p. 504).

Power argued that the U.S. government should act more decisively in the face of genocidal violence, not only on moral grounds but also on the basis of "enlightened self-interest":

[S]ecurity for Americans at home and abroad is contingent on international stability, and there is perhaps no greater source of havoc than a group of well-armed extremists bent on wiping out a people on ethnic, national, or religious grounds. Western governments have generally tried to contain genocide by appeasing its architects. But the sad record of the last century shows that the walls the United States tries to build around genocidal societies almost inevitably shatter. States that murder and torment their own citizens target citizens elsewhere....Citizens victimized by genocide or abandoned by the international community do not make good neighbors, as their thirst for vengeance, their irredentism, and their acceptance of violence as a means of generating change can turn them into future threats (Power, 2003, p. 513).

The 2008 report of the Albright-Cohen Genocide Prevention Task Force echoed the themes sounded in Power's book, describing genocide and mass atrocities not only as "a direct assault on universal human values, including most fundamentally the right to life," but also as a threat to "core U.S. national interests." The report observed:

[G]enocide fuels instability, usually in weak, undemocratic, and corrupt states. It is in these same types of states that we find terrorist recruitment and training, human trafficking, and civil strife, all of which have damaging spillover effects for the entire world. (Albright \& Cohen, 2008, p. xx)
By failing to take timely preventive action, the report declared, "we inevitably bear greater costs-in feeding millions of refugees and trying to manage long-lasting regional crises." Moreover,

America's standing in the world-and our ability to lead-is eroded when we are perceived as bystanders to genocide. We cannot be viewed as a global leader and respected as an international partner if we cannot take steps to avoid one of the greatest scourges of humankind. No matter how one calculates U.S. interests, the reality of our world today is that national borders provide little sanctuary from international problems. Left unchecked, genocide will undermine American security. (Albright \& Cohen, 2008, pp. xv, xx)

Both Power's book and the Albright-Cohen report started from the premise that moral or humanitarian concerns alone were insufficient grounds for motivating action by senior U.S. policymakers. Instead, they argued, it was essential to reframe atrocities prevention as a national security priority. In addition to imperiling "universal human values" including "the right to life," they contended, mass atrocities undermined international stability, facilitated "terrorist recruitment and training," and promoted the "acceptance of violence as a means of generating change."

The sociologist Ervin Goffman (1974) has defined a "frame" as an interpretive schema for organizing and making meaning out of otherwise chaotic social experience. He notes that a frame "allows its user to locate, perceive, identify, and label a seemingly infinite number of concrete occurrences defined in its terms" ( $p$. 21). A frame may take many forms. It may consist of an explicitly formulated set of principles (e.g. the rules to a game of checkers or chess), but more often it is amorphous and articulated only implicitly-involving a set of shared values, assumptions, narratives, metaphors, or social conventions. In recent decades, the concept of framing has made inroads into a wide range of fields including psychology (e.g. Levin \& Schneider, 1998; Tversky \& Kahneman, 1981), behavioral economics (Kahneman, 2003), public health (Dorfman, Wallack, \& Woodruff, 2005), media studies (Scheufele, 1999), and electoral politics (Lakoff, 1996, 2004; Lempert \& Silverstein, 2012).

One common framing device is what the international relations scholar Lawrence Freedman (2006) calls the strategic narrative: a "compelling story" that "can explain events convincingly and from which inferences can be drawn" (p. 22). In the context of contemporary international conflict, in which small organizations such as insurgencies and terrorist groups can exert influence that far exceeds their material resources, strategic narratives are particularly important framing devices. As John Arquilla and David Ronfeldt 
(2001) point out, narratives "provide a grounded expression of people's experiences, interests and values." They both "express a sense of identity and belonging" and "communicate a sense of cause, purpose, and mission" (p. 328; see also Levinger, 2013, pp. 113-134; Martinez, Agoglia, \& Levinger, 2013). This enables dispersed groups to define and pursue a common mission in the absence of a centralized hierarchical authority.

If strategic narratives are essential for non-state actors seeking to exert influence on the global stage, they are equally vital for those at the pinnacle of powersuch as heads of state-who need to motivate and coordinate actions by thousands or even millions of subordinates, as well as to build and sustain coalitions involving diverse domestic constituencies and international partners. Especially in times of crisis or rapid change, international leadership is inextricably intertwined with the practice of storytelling.

This essay will analyze three ways in which President Obama has framed the stories he has told about potential or actual incidents of mass atrocities in Libya, Syria, and Iraq: the "legalistic" (or "liberal internationalist"), the "moralistic," and the "security" frame. I use the terms "legalistic" and "moralistic," rather than "legal" and "moral," because these speeches contain little rigorous legal or moral reasoning. Moreover, many of Obama's security-related arguments in these speeches utilized visceral and emotionally laden words such as "plots," "threats," "9/11," and "terrorists," rather than more neutral terms such as "national security" or "national interests." In a sense, one might surmise that Obama's principal objective in these speeches was to convey the aura of legality, morality, and security (or illegality, immorality, and insecurity), rather than an iron-clad logical exposition.

\section{Methodology}

The paper analyzes fifteen presidential speeches and statements delivered between 2011 and 2015. Five of these speeches or statements discuss the conflict in Libya (2011-2012), five discuss the conflict in Syria, focusing on actions by the regime of Syrian president Bashar al-Assad (2011-2013), and five discuss the U.S. response to actions by the Islamic State in Iraq and the Levant (ISIL) (2014-2015). The essay utilizes two methods for analyzing these documents, one quantitative and the other qualitative. The quantitative method involves comparing the frequencies of "legalistic," "moralistic," and "security-related" words in the speeches. The qualitative method draws on work by the linguist Roman Jakobson on the "poetics" of language, which explores how the meaning of a text is shaped through the use of patterns of repetition and contrast (Jakobson, 1960; see also Levinger, 1990, Lempert \& Silverstein, 2012).

\subsection{The Quantitative Method: Calculating Word Frequencies}

In the conduct of foreign policy, the U.S. president is a uniquely powerful individual. Unlike in the domestic arena, where the president is often reduced to the role of "cajoler-in-chief" - catering to the demands of Congress, the courts, interest groups, and campaign donors, among others-in his dealings overseas the president possesses the de jure or de facto authority to act with considerable autonomy. For example, he can initiate limited military attacks (including bombing raids and drone or cruise missile strikes), establish no-fly zones, deploy U.S. military personnel for humanitarian operations or other short-term missions, impose sanctions, and engage in bilateral and multilateral diplomatic initiatives, without Congressional approval.

Although, in the short run, the President often has the capacity to act unilaterally without having to persuade his constituents of the wisdom, legitimacy, or even the legality of his decisions, persuasive public communication is essential in at least three respects: First, the President must enlist support for his policies from the U.S. Congress and U.S. public opinion in order to sustain resource-intensive foreign policy initiatives over the long term. Second, the President often needs to recruit support from international partners and neutralize international opposition. Finally, the President may find it useful to signal American intentions and resolve to potential enemies in order to increase U.S. leverage and deter hostile acts.

By calculating the frequencies with which President Obama has used various types of words in speeches concerning potential or actual incidents of mass atrocities, we can determine which rhetorical frame he considered most likely to persuade his domestic and international audiences in particular situations. Moreover, we can distinguish the rhetorical strategies that he employed when he wanted to justify robust action by the U.S. government from those he employed when he wanted to justify inaction, or only symbolic action, in response to atrocities. The words associated with the legalistic, moralistic, and security frames are shown in Table 1.

The frequencies of each of these clusters of words are calculated as in the examples below:

The Legalistic (Liberal Internationalist) Frame (Libya, February 2013):

"[T]hroughout this period of unrest and upheaval across the region the United States has maintained a set of core principles which guide our approach....These actions violate international norms and every standard of common decency.... The United States also strongly supports the universal rights of the Libyan people. That includes the rights 
of peaceful assembly, free speech, and the ability of the Libyan people to determine their own destiny. These are human rights. They are not negotiable" (Obama, 2011a).

Frequency: 130 words per 1,000 (10 words out of 77)

The Moralistic Frame (ISIL, September 2014):

"In a region that has known so much bloodshed, these terrorists are unique in their brutality. They execute captured prisoners. They kill children. They enslave, rape, and force women into marriage" (Obama, 2014b).

Frequency: 161 words per 1,000 (5 words out of 31)

The Security Frame (ISIL, September 2014):

"Still, we continue to face a terrorist threat. We cannot erase every trace of evil from the world, and small groups of killers have the capacity to do great harm. That was the case before 9/11, and that remains true today. That's why we must remain vigilant as threats emerge. At this moment, the greatest threats come from the Middle East and North Africa, where radical groups exploit grievances for their own gain" (Obama, 2014b).

Frequency: 110 words per 1,000 ( 8 words out of 73 )

Table 1. Coding of legalistic, moralistic, and securityrelated words.

\begin{tabular}{ll}
\hline Legalistic Words & democra\#, free\#, global\#, \\
& human\#, international\#, law\#, \\
& $\begin{array}{l}\text { legal\#, norm\#, peace\#, } \\
\text { principle\#, right\#, rule\#, } \\
\text { universal\#, value\# }\end{array}$ \\
Moralistic Words & atroc\#, attack\# (other), blood\#, \\
& brutal\#, destroy\# (other), \\
& destruction (other), evil\#, \\
& genoc\#, horr\#, innocent\#, kill\# \\
& (other), massacre\#, murder\# \\
& (other), rape\#, slaughter\#, \\
& \#slave\#, victim\#, violen\# (other)
\end{tabular}

Security-related

Words

Visceral

9/11, Al Qaeda, attack\# (US), destroy\# (US), destruction (US), kill\# (US), murder\# (US), plot\#, terror\#, threat\#, vigilant\#, violen\# (US)

Abstract

aggress\#, extrem\#, interest\#, national\#, radical\#, secur\#

As these examples reveal, the coding methodology employed here is more art than science. Certain words are omitted from the word count that arguably should be included (e.g. "standard," "assembly," "determine," "negotiable" in the legalistic frame; "execute" and "force" in the moralistic frame; "harm" in the security frame). Moreover, the boundaries among the various frames are amorphous. For example, the moralistic passage quoted above includes the word "terrorists," which is coded as a security-related word. Conversely, the security-related passage contains the word "evil," coded as a moralistic word.

Perhaps most interestingly, certain words (attack\#, destroy\#, destruction, kill\#, murder\#, violen\#) migrate between categories, depending on the contexts in which they are used. They are coded as moralistic words if they refer, implicitly or explicitly, to violence against non-American victim groups. The same terms are coded as visceral security-related words if they refer, implicitly or explicitly, to violence involving Americans. In the above examples, the word "kill" in the sentence, "They kill children," is coded as a moralistic word; whereas the word "killers" in the phrase "small groups of killers" is coded as a security-related word.

Although this word-counting methodology is rough, it reveals striking patterns in President Obama's choice of rhetorical strategies for describing incidents of mass atrocities in North Africa and the Middle East, which will be discussed below.

\subsection{The Qualitative Method: Analyzing Poetics}

One key-and perhaps unsurprising-finding of this essay is that rhetoric about violence directed against members of the "in-group" (those closely associated with the American national community) is far more likely to motivate robust policy responses by the U.S. government than rhetoric about similar acts of violence directed against members of "out-groups" (those seen as outsiders to the American national community). Thus, for example, "small groups of killers" who threaten the U.S. homeland are more likely to attract a vigorous response than groups that "kill children" in Iraq. Yet, political leaders have considerable flexibility in terms of how and where they draw the boundaries between the in-group and the outgroup. For example, depending on the context, citizens of close U.S. allies such as the United Kingdom or Israel might be characterized as in-group members, whereas citizens of other allied states such as India or Saudi Arabia might be relegated to the out-group.

In a classic essay on "Linguistics and Poetics," Roman Jakobson observed that the semiotic content of a text is determined not only by its "referential function" (the ways in which language points to objects and phenomena in the world) but also by its "poetic function" (the ways in which meaning is constructed through the juxtaposition of particular elements of a text with each other). "In poetry," he wrote, "any se- 
quence of semantic units strives to build an equation. Similarity superimposed on contiguity imparts to poetry its thoroughgoing symbolic, multiplex, polysemantic essence." Just as "words similar in sound are drawn together in meaning," the reiteration of patterns of parallels and contrasts in a text results in the "reification of a poetic message" and the "conversion of a message into an enduring thing" (Jakobson, 1960, pp. 370-371).

In political speeches, meanings are established and reinforced in large part through the strategic use of the "poetic function." This is especially true for gifted political orators such as Barack Obama, who first catapulted to national fame on the basis of an extended poem that he delivered as the keynote address to the Democratic National Convention in July 2004:

[T]here's not a liberal America and a conservative America; there's the United States of America. There's not a black America and white America and Latino America and Asian America; there's the United States of America....We are one people, all of us pledging allegiance to the stars and stripes, all of us defending the United States of America (Obama, 2004).

An analysis of the poetic structure of President Obama's political speeches on Libya, Syria, and ISIL can illuminate the ways in which he draws the line between the in-group and the out-groups-and implicitly, the ways in which he argues for either bold or tepid policy responses to threats of mass atrocities. Table 2 presents a poetic analysis of a passage from Obama's speech of September 10, 2014 in which he announced the expansion of the U.S. military campaign to "degrade and ultimately destroy the terrorist group known as ISIL" (Obama, 2014b).

Two paragraphs of this speech were devoted to celebrating the success of the U.S. rescue effort for members of Iraq's Yezidi community who had been trapped by ISIL forces on Mt. Sinjar in Northern Iraq. In a speech delivered five weeks earlier, on August 7, Obama had described the Yezidi as a "small and ancient sect." He had declared that "ISIL forces below have called for the systematic destruction of the entire Yezidi people, which would constitute genocide" (Obama, 2014a).

In the September 10 speech, Obama praised the efforts of American "pilots who bravely fly in the face of danger above the Middle East" in order to defend threatened civilians:

When we helped prevent the massacre of civilians trapped on a distant mountain, here's what one of them said: "We owe our American friends our lives. Our children will always remember that there was someone who felt our struggle and made a long journey to protect innocent people." That is the difference we make in the world. And our own safety-our own security-depends upon our willingness to do what it takes to defend this nation, and uphold the values that we stand for-timeless ideals that will endure long after those who offer only hate and destruction have been vanquished from the Earth. (Obama, 2014b)

Table 2 charts the relationships between "in-group" (on the left) and "out-groups" (on the right) in the above passage.

This passage seamlessly combines the moralistic frame (preventing "the massacre of innocent civilians trapped on a distant mountain") with the security frame (vanquishing terrorists "who offer only hate and destruction"). As Table 2 indicates through the use of boldface words, the passage also knits together two groups identified by the word "we": the American saviors (on the left) and the Yezidi innocents (on the right). The grammatical structure of the first sentence is particularly clever: "When we helped prevent the massacre of civilians trapped on a distant mountain, here's what one of them said: 'We owe our American friends [them] our lives." By the end of the sentence, the initial "we" has become "them," and the initial "them" has become "we," suggesting an intimate bond between the rescuer and the rescued. This bond is accentuated by the intimacy of the verbs in the passage: the Yezidi say that the Americans "felt our struggle," and they pledge that their "children will always remember" their benefactors.

Despite the mutual empathy that Obama indicates exists between the Americans and the Yezidi, he is also careful to highlight both the geographic and the cultural distance between these two groups. The Americans had to make a "Iong journey" to a "distant mountain" (which they flew "above") in order to save the Yezidi. Moreover, the Yezidi are passive: they "say" how grateful they are, they "owe" the Americans their lives, they promise to "remember" their benefactors. The Americans, by contrast, are actively heroic: they "prevent the massacre of civilians," they "protect innocent people," they "do what it takes to defend this nation," and they will "vanquish" terrorists "from the earth." Their actions above that distant mountain were altruistic: at no point does Obama suggest that the security of the American people depended upon the survival of the Yezidi. 
Table 2. The poetics of persuasion-Saving the Yezidi and Bombing ISIL.

\begin{tabular}{|c|c|c|}
\hline In-Group & Verb Phrase & $\begin{array}{l}\text { Out-Group } \\
(+)=\text { positively valued } \\
(-)=\text { negatively valued }\end{array}$ \\
\hline \multicolumn{3}{|l|}{ When } \\
\hline \multirow[t]{5}{*}{ we } & helped prevent the massacre of & civilians trapped on a distant mountain (+) \\
\hline & here's what & one of them $(+)$ \\
\hline & said: & \\
\hline & & We $(+)$ \\
\hline & owe & \\
\hline \multicolumn{3}{|l|}{ our American friends } \\
\hline & & our lives. (+) \\
\hline & & Our children (+) \\
\hline & will always remember that there was & \\
\hline \multirow[t]{2}{*}{ someone } & who felt & our struggle (+) \\
\hline & and made a long journey to protect & innocent people. (+) \\
\hline \multicolumn{3}{|l|}{ This is the difference } \\
\hline we & make in the world. & \\
\hline \multicolumn{3}{|c|}{ And our own safety- } \\
\hline our own security- & depends upon & \\
\hline our willingness & to defend & \\
\hline this nation, & and uphold & \\
\hline the values that we & stand for- & \\
\hline \multirow[t]{2}{*}{ timeless ideals } & that will endure long after & those who offer only hate and destruction (-) \\
\hline & have been vanquished from the earth. & \\
\hline
\end{tabular}

\section{Case Studies}

Table 3 shows the frequency (per 1,000 words) with which President Obama used legalistic, moralistic, and security-related words (as identified above in Table 1) in fifteen speeches concerning Libya, Syria, and ISIL delivered between February 2011 and February 2015. The word clusters with the highest frequencies (greater than 10 per 1,000 words) are shown in boldface. A frequency of 10 per 1,000 words corresponds to approximately one word per paragraph of a written text-or one word per minute in the delivery of a speech.

The Libya speeches analyzed here include four speeches from 2011 and one from 2012. The first three (of February 23, March 18, and March 28, 2011) were delivered before and during the UN-authorized military intervention in Libya that began on March 19 The fourth speech (of September 20, 2011) was delivered at the UN four weeks after the fall of Tripoli to rebel forces; and the fifth (of September 25, 2012) was Obama's annual address to the UN General Assembly delivered two weeks after the killing of U.S. Ambassador Chris Stevens in Benghazi (Obama, 2011a, 2011b, 2011c, 2011h, 2012c).

The Syria speeches include two early condemnations of President Bashar al-Assad's use of violence against civilians (of April 22 and August 18, 2011), followed by two speeches denouncing the Syrian regime's use of chemical weapons (August 31 and September 10, 2013) and Obama's address to the UN General Assembly on September 24, 2013, which devoted considerable attention to the Syrian conflict (Obama, 2011d, 2011g, 2013a, 2013c, 2013d). 
Table 3. Word frequencies in President Obama's speeches on Libya, Syria, and ISIL, 2011-2015 (per 1,000 words).

\begin{tabular}{|c|c|c|c|c|c|}
\hline \multicolumn{6}{|c|}{ Libya-related Speeches 2011-2012 } \\
\hline Date & $2 / 23 / 11$ & $3 / 18 / 11$ & $3 / 28 / 11$ & $9 / 20 / 11$ & $9 / 25 / 12$ \\
\hline Word count & 789 & 1257 & 3410 & 1769 & 4052 \\
\hline Legalistic words & 38.02 & 22.28 & 11.73 & 13.57 & 20.48 \\
\hline Moralistic words & 8.87 & 13.52 & 9.68 & 6.78 & 4.69 \\
\hline Security-related words & 5.07 & 4.77 & 6.45 & 7.35 & 9.87 \\
\hline Visceral & 1.27 & 1.59 & 1.17 & 2.83 & 5.92 \\
\hline Abstract & 3.80 & 3.18 & 4.69 & 4.52 & 3.95 \\
\hline \multicolumn{6}{|c|}{ Syria-related Speeches 2011-2013 } \\
\hline Date & $4 / 22 / 11$ & $8 / 18 / 11$ & $8 / 31 / 13$ & $9 / 10 / 13$ & $9 / 24 / 13$ \\
\hline Word count & 320 & 691 & 1435 & 2205 & 5530 \\
\hline Legalistic words & 37.50 & 18.81 & 9.06 & 16.33 & 18.63 \\
\hline Moralistic words & 12.50 & 11.58 & 6.97 & 6.35 & 5.97 \\
\hline Security-related words & 15.63 & 1.45 & 6.97 & 12.24 & 11.57 \\
\hline Visceral & 6.25 & 0.00 & 0.70 & 6.34 & 3.98 \\
\hline Abstract & 9.38 & 1.45 & 6.27 & 5.90 & 7.59 \\
\hline \multicolumn{6}{|c|}{ ISIL-related Speeches 2014-2015 } \\
\hline Date & $8 / 7 / 14$ & $9 / 10 / 14$ & $9 / 23 / 14$ & $2 / 11 / 15$ & $2 / 19 / 15$ \\
\hline Word count & 488 & 1832 & 531 & 1206 & 2500 \\
\hline Legalistic words & 8.20 & 7.64 & 1.88 & 4.98 & 10.00 \\
\hline Moralistic words & 22.54 & 8.73 & 0.00 & 2.49 & 5.60 \\
\hline Security-related words & 28.69 & 31.66 & 37.66 & 19.90 & 25.20 \\
\hline Visceral & 22.54 & 24.02 & 33.90 & 14.10 & 19.60 \\
\hline Abstract & 6.15 & 7.64 & 3.77 & 5.80 & 5.60 \\
\hline
\end{tabular}

The ISIL speeches begin with Obama's announcement on August 7, 2014 that he has authorized military operations to defend U.S. personnel in Iraq, as well as Yezidi civilians trapped on Mt. Sinjar in Iraq and threatened with destruction by ISIL. The next two speeches (September 10 and September 23, 2014) report on the progress of the campaign against ISIL. The fourth speech (February 11, 2015) offers a further status report on U.S. and coalition military operations in Iraq and Syria against ISIL; and the fifth speech is Obama's address to the Summit on Countering Violent Extremism held at the U.S. State Department on February 19, 2015 (Obama, 2014a, 2014b, 2014c, 2015a, 2015b).

Several initial conclusions can be drawn from the patterns of word use identified in Table 3:

(1) Obama's speeches on Libya in 2011-2012 were all dominated by the legalistic (or liberal internationalist) frame, and his speeches on ISIL in 2014-2015 were all dominated by the security frame.

(2) In both the Libya-related and the ISIL-related speeches, the framing showed a high degree of "stickiness." In other words, Obama continued to frame the events on the ground in similar ways despite sometimes dramatic changes in the international and U.S. domestic political context. For example, Obama's speech to the UN General Assembly about Libya in September 2012, which was delivered after the killing of Ambassador Chris Stevens in Benghazi, and in the midst of the 2012 U.S. presidential campaign, discussed the conflict in similar terms as his initial speeches justifying the U.S. military intervention in Libya in February-March 2011. Likewise, there was a high degree of continuity in Obama's framing of the U.S. response to ISIL from the onset of U.S. military operations in Iraq in August 2014 through the Countering Violent Extremism address in February 2015.

(3) In addressing the conflict in Syria, Obama also favored the legalistic frame, but the pattern was less consistent, with the moralistic and security frames appearing to a greater or lesser extent in different contexts.

(4) The most significant pattern in Obama's public communication concerning the conflict in Syria was his relative silence on this topic. From Au- 
gust 2011 until August 2013, as the security and humanitarian conditions in Syria disintegrated, Obama rarely spoke publicly at any length about the conflict. The notable exceptions were a press conference and a speech in 2012 in which he warned the Assad regime against the use of chemical weapons.

(5) In none of the fifteen speeches analyzed here was moralistic framing alone utilized to justify a robust U.S. response to potential or actual mass atrocities. Moralistic framing appeared alongside the dominant legalistic framing in Obama's initial speeches about Libya in March-April 2011, and alongside the dominant security framing in his initial speeches about ISIL in AugustSeptember 2014. In both cases, the moralistic framing subsided in his subsequent speeches on these topics.

Each of these findings is discussed in further detail below.

\subsection{Libya: Democracy Ascendant}

The 2008 report of the Genocide Prevention Task Force placed so much emphasis on the relationship between atrocities prevention and U.S. national security largely because the task force members believed that senior policymakers would take decisive action to avert genocide or mass atrocities only if they believed that core U.S. national security interests were at stake.

At first blush, President Obama's rhetoric concerning the Libya crisis in 2011 appears to undermine this premise. The legalistic (or liberal internationalist) frame dominated his speeches of February and March 2011, when the U.S. was planning and initiating its military response to the Qaddafi regime's offensive in Eastern Libya. Legalistic words occurred 38.02 and 22.28 times per thousand words in his speeches of February 23 and March 18 respectively, followed by moralistic words (8.87 and 13.52 words per thousand). The security frame was a distant third (5.07 and 4.77 words per thousand), and hardly any of the securityrelated terms were visceral words like "terrorism" or "9/11."

In delivering an ultimatum to Libyan President Moammar Qaddafi on March 18, the day before initiating U.S. military strikes, Obama described the stakes of the conflict as follows:

Now, here is why this matters to us. Left unchecked, we have every reason to believe that Qaddafi would commit atrocities against his people. Many thousands could die. A humanitarian crisis would ensue. The entire region could be destabilized, endangering many of our allies and partners. The calls of the Libyan people for help would go un- answered. The democratic values that we stand for would be overrun. Moreover, the words of the international community would be rendered hollow. And that's why the United States has worked with our allies and partners to shape a strong international response at the United Nations. Our focus has been clear: protecting innocent civilians within Libya, and holding the Qaddafi regime accountable. (Obama, 2011b)

As James Mann observes, Obama's decision to initiate a humanitarian intervention in Libya was "momentous." According to Mann, most officials within the Obama administration believed that Libya "was not itself of compelling strategic interest to the United States; America's only arguable strategic interest on this issue lay in maintaining strong relationships with close allies who were supporting the United States elsewhere in the world" (Mann, 2012, p. xv).

The military intervention in Libya took place at an extraordinary historical moment, in the midst of the euphoria following the relatively quick and peaceful revolutions in Tunisia and Egypt. Qaddafi had issued chilling warnings against the people of Benghazi and other cities in Eastern Libya, which were reminiscent of the threats by Rwanda's génocidaires that had preceded the killing of 800,000 Rwandan Tutsi and moderate Hutu in that country in 1994 (Chollet \& Fishman, 2015, pp. 154-155). Moreover, Libya's desert landscape, and the geographic separation of regime forces in the country's West from the rebel-held cities in the East, made it feasible for the U.S. and its allies to intervene militarily without putting large numbers of civilians at risk.

The U.S. leadership role in Operation Odyssey Dawn, the military operation against Qaddafi's forces that began on March 19, 2011, lasted only about a week. Before unleashing attacks on Libyan air defenses and key military targets, Obama had secured an agreement with British Prime Minister David Cameron and French president Nicolas Sarkozy that

after a few days, the United States would step back and leave it to the British, French and other allies to continue the military campaign on their own....After the first few days, Obama kept American forces out of the combat, despite occasional British and French appeals to the United States to rejoin the air campaign. (Mann, 2012, p. xvi)

The limited duration and scope of the U.S. military intervention in Libya suggests that the power of liberal internationalist rhetoric to motivate vigorous responses to threats of mass atrocities remains unproven.

One striking dimension of Obama's Libya-related speeches is that, although he employed liberal internationalist rhetoric to justify the initial U.S.-led military intervention in early 2011, he subsequently used the 
same rhetorical framing strategy to justify American inaction as the security situation in Libya deteriorated. In September of that year, after the Libyan rebels had seized control of Tripoli but while Qaddafi still remained at large, Obama congratulated the people of Libya on "writing a new chapter in the life of their nation" by building a "a future that is free and democratic and prosperous." Obama declared:

Now, even as we speak, remnants of the old regime continue to fight. Difficult days are still ahead. But one thing is clear -- the future of Libya is now in the hands of the Libyan people. For just as it was Libyans who tore down the old order, it will be Libyans who build their new nation. (Obama, 2011g)

A year later, Obama addressed the UN General Assembly under less auspicious circumstances. On September 11, 2012, the U.S. Ambassador to Libya, Chris Stevens, was killed along with three of his colleagues in an attack on the U.S. consulate in Benghazi. The International Crisis Group issued a report describing this incident as "a stark reminder of Libya's security challenges" that should "serve as a wake-up call." Libya, it warned, was devolving into "a country of regions and localities pulling in different directions, beset by intercommunal strife and where well-armed groups freely roam" (International Crisis Group, 2012).

Yet Obama, while mourning Stevens' death and promising to be "relentless in tracking down the killers and bringing them to justice," remained upbeat about Libya's prospects in his September 25 speech at the UN:

[E]ven as there will be huge challenges to come with a transition to democracy, I am convinced that ultimately government of the people, by the people, and for the people is more likely to bring about the stability, prosperity, and individual opportunity that serve as a basis for peace in our world. So let us remember that this is a season of progress. For the first time in decades, Tunisians, Egyptians and Libyans voted for new leaders in elections that were credible, competitive, and fair. This democratic spirit has not been restricted to the Arab world.... Around the globe, people are making their voices heard, insisting on their innate dignity, and the right to determine their future (Obama, 2012c).

In other words, because democracy was on the march during this "season of progress," the wake-up call sounded by the International Crisis Group and other organizations could be put on hold.

\subsection{Syria: The Long Silence}

One of the most striking aspects of President Obama's public comments concerning the crisis in Syria since 2011 has been their rarity. On April 22, 2011, Obama issued a 300-word statement condemning "in the strongest possible terms the use of force by the Syrian government against demonstrators" and warning: "This outrageous use of violence to quell protests must come to an end now" (Obama, 2011d). Four weeks later, on May 19, he devoted three paragraphs of a speech on the Middle East and North Africa to discussing the situation in Syria. In this speech, Obama again condemned the violence and announced stepped-up sanctions against the Syrian regime. Obama declared:

The Syrian people have shown their courage in demanding a transition to democracy. President Assad now has a choice: he can lead that transition, or get out of the way (Obama, 2011e).

President Obama's next public remarks on Syria did not come until three months later, on August 18, 2011, when he issued a 700-word statement accompanying an executive order that further tightened financial and trade sanctions on the Syrian government. In this statement, Obama reiterated the themes found in his earlier comments on this conflict:

The future of Syria must be determined by its people, but President Bashar al-Assad is standing in their way. His calls for dialogue and reform have rung hollow while he is imprisoning, torturing, and slaughtering his own people. We have consistently said that President Assad must lead a democratic transition or get out of the way. He has not led. For the sake of the Syrian people, the time has come for President Assad to step aside. The United States cannot and will not impose this transition upon Syria. It is up to the Syrian people to choose their own leaders, and we have heard their strong desire that there not be foreign intervention in their movement. What the United States will support is an effort to bring about a Syria that is democratic, just, and inclusive for all Syrians. We will support this outcome by pressuring President Assad to get out of the way of this transition, and standing up for the universal rights of the Syrian people along with others in the international community (Obama, 2011g).

As shown in Table 2, this speech was dominated by the legalistic and moralistic rhetorical frames, with an almost total absence of security-related words. Obama denounced Assad for "imprisoning, torturing, and slaughtering his own people," and repeated his demand that "President Assad must lead a democratic transition or get out of the way." Yet, Obama also clearly signaled his unwillingness to apply any coercive instruments beyond economic sanctions to force Assad 
from power. "The United States cannot and will not impose this transition upon Syria," he declared, and asserted that the Syrian people themselves had expressed "their strong desire that there not be foreign intervention in their movement."

Table 4 maps the poetic structure of the first seven sentences of the above passage from Obama's August 2011 speech. This poetic analysis makes clear the emphatic boundaries that Obama drew between the "ingroup" of the American people and the "out-group" of the Syrians. It also highlights the passivity of the stance toward the Syrian conflict that Obama advocated.

Table 4 reveals the strenuousness of President
Obama's effort to distance the U.S. government from the ongoing conflict in Syria. Unlike in his subsequent speech of September 2014 concerning ISIL, in which brave American pilots flying above the Middle East "felt the struggle" of the Yezidi, the American government and people barely made an appearance here (apart from two uses of the word "we," one of the "United States," and one reference to the undesirability of "foreign intervention"). Moreover, the verbs that Obama employed to describe American action, or inaction (shown in boldface in Table 4), were remarkably passive.

Table 4. President Assad is standing in the way.

\begin{tabular}{|c|c|c|}
\hline In-Group & Verb Phrase & $\begin{array}{l}\text { Out-Group } \\
(+)=\text { positively valued } \\
(-)=\text { negatively valued }\end{array}$ \\
\hline \multirow[t]{10}{*}{ The future of } & & Syria \\
\hline & must be determined by & its people, $(+)$ \\
\hline & but & President Bashar al-Assad (-) \\
\hline & is standing in & their way. $(+)$ \\
\hline & & His calls (-) \\
\hline & for & dialogue and reform (+) \\
\hline & have rung hollow while & he $(-)$ \\
\hline & is imprisoning, & \\
\hline & torturing, and & \\
\hline & slaughtering & his own people. $(+)$ \\
\hline \multirow[t]{7}{*}{ We } & have consistently said that & President Assad (-) \\
\hline & must lead & a democratic transition $(+)$ \\
\hline & or get out of & the way. (+) \\
\hline & & $\mathrm{He}(-)$ \\
\hline & has not led. For the sake of & the Syrian people, $(+)$ \\
\hline & the time has come for & President Assad (-) \\
\hline & to step aside. & \\
\hline \multirow[t]{5}{*}{ The United States } & cannot and & \\
\hline & will not impose & this transition $(+)$ \\
\hline & upon & Syria. \\
\hline & It is up to & the Syrian people $(+)$ \\
\hline & to choose & their own leaders, and $(+)$ \\
\hline \multirow[t]{2}{*}{ we } & have heard their strong desire & \\
\hline & that there not be & \\
\hline foreign intervention & in & their movement....(+) \\
\hline
\end{tabular}


In the speech on the Yezidi, the Americans acted as saviors of innocents and vanquishers of terrorists, while the Yezidi were associated with passive verbs ("say," "remember," "owe"). In the August 2011 speech on Syria, by contrast, the Americans were passive while the Syrians played the active roles. Obama noted that the U.S. government "has consistently said that President Assad must lead a democratic transition"; and that we "have heard" the Syrians' "strong desire that there not be a foreign intervention." The only active verbs concerning the U.S. government were employed in the negative: "The United States cannot and will not impose this transition upon Syria."

Over the subsequent two years, from August 2011 until August 2013, President Obama barely mentioned Syria in his public speeches, apart from issuing a "red line" against the use of chemical weapons by the Assad regime in August 2012 (Obama, 2012b) and reiterating this warning in December of that year (Obama, 2012d). In his speech to the UN General Assembly of September 2011, Obama devoted two paragraphs to discussing Syria (Obama, 2011i); on the same occasion the following year, Obama devoted three paragraphs to the Syrian conflict (Obama, 2012c).

The one great exception to Obama's passive stance toward Syria concerned the use of chemical weapons by the Syrian regime. Obama repeatedly and forcefully made the case that the use of chemical weapons against Syrian civilians represented not just a violation of the laws of war, but also a direct threat to U.S. national security. For example, in his weekly address of September 7, 2013, Obama declared:

We cannot turn a blind eye to images like the ones we've seen out of Syria. Failing to respond to this outrageous attack would increase the risk that chemical weapons could be used again; that they would fall into the hands of terrorists who might use them against us, and it would send a horrible signal to other nations that there would be no consequences for their use of these weapons. All of which would pose a serious threat to our national security. (Obama, 2013b)

Despite this vigorous rhetoric, Obama and his advisors reportedly did not make an all-out effort to secure Congressional approval for military strikes against Syria in September 2013 (Weiss, 2014). Ultimately, the U.S. response to the Assad regime's chemical weapons attacks was a diplomatic agreement, brokered by the Russian government, under which the Syrian regime agreed to destroy its chemical weapons stock, but under which no one would be held accountable for war crimes against Syrian civilians. Moreover, by focusing this agreement specifical- ly on chemical weapons, the Obama administration tacitly withheld any objection to the Syrian regime's commission of atrocities against its own civilians, provided that it utilized only conventional weapons to carry out these attacks.

\subsection{ISIL: "If You Threaten America..."}

In justifying military strikes against Libya in his speeches of March 2011, President Obama had framed his arguments in moralistic as well as liberal internationalist terms. The shocking advance of ISIL forces from Syria into Iraq in the summer of 2014 brought this regional conflict back into focus for the U.S. public and its political leaders. Obama again used moralistic appeals to advocate a muscular military response by the U.S. government. This time, however, the moralistic rhetoric was paired not with arguments grounded in international law but with visceral security-related rhetoric reminiscent of the Bush administration's Global War on Terror.

Obama's speech of September 10, 2014 announcing the expansion of U.S. military action against ISIL used the word "terror" or one of its variants 19 times, and the words "threat" or "threaten" 17 times. These terrorist threats, he declared, warranted a decisive and uncompromising response:

I have made it clear that we will hunt down terrorists who threaten our country, wherever they are. That means I will not hesitate to take action against ISIL in Syria, as well as Iraq. This is a core principle of my presidency: if you threaten America, you will find no safe haven. (Obama, 2014b)

Table 5, which presents a poetic analysis of the above passage, makes clear how far Obama had moved from his passive stance vis-à-vis Syrian aggression in his speech of August 2011. In the earlier speech, the U.S. government was depicted as standing on the margins of the conflict in Syria, offering "support" for a "democratic, just, and inclusive" Syria. But now, the U.S. stood front and center in this conflict, taking an active and if necessary a belligerent role, ready to "hunt down terrorists who threaten our country."

This speech reveals Obama in full "threat and response" mode. "[T]errorists...threaten," he declares; "I will...take action." And then: "you threaten," but "you will find no safe haven." In this speech the out-group has been rhetorically expanded to include not only "terrorists," but also "you." Furthermore, the boundaries around the out-group have been hardened to comprise solely malevolent actors: "terrorists," "ISIL," and "you." 
Table 5. No safe haven for terrorists.

\begin{tabular}{lll}
\hline In-Group & Verb Phrase & Out-Group \\
& & $(-)$ = negatively valued \\
\hline We & have made it clear that & terrorists who (-) \\
& will hunt down & \\
& threaten & they (-) \\
our country, & wherever & \\
& are. That means & \\
I & will not hesitate & ISIL (-) \\
& to take action against & in Syria, (-) \\
& & as well as Iraq. (-) \\
This & is & \\
a core principle of & if & you (-) \\
my presidency: & threaten & \\
& & \\
\hline
\end{tabular}

Table 6. Countering violent extremism.

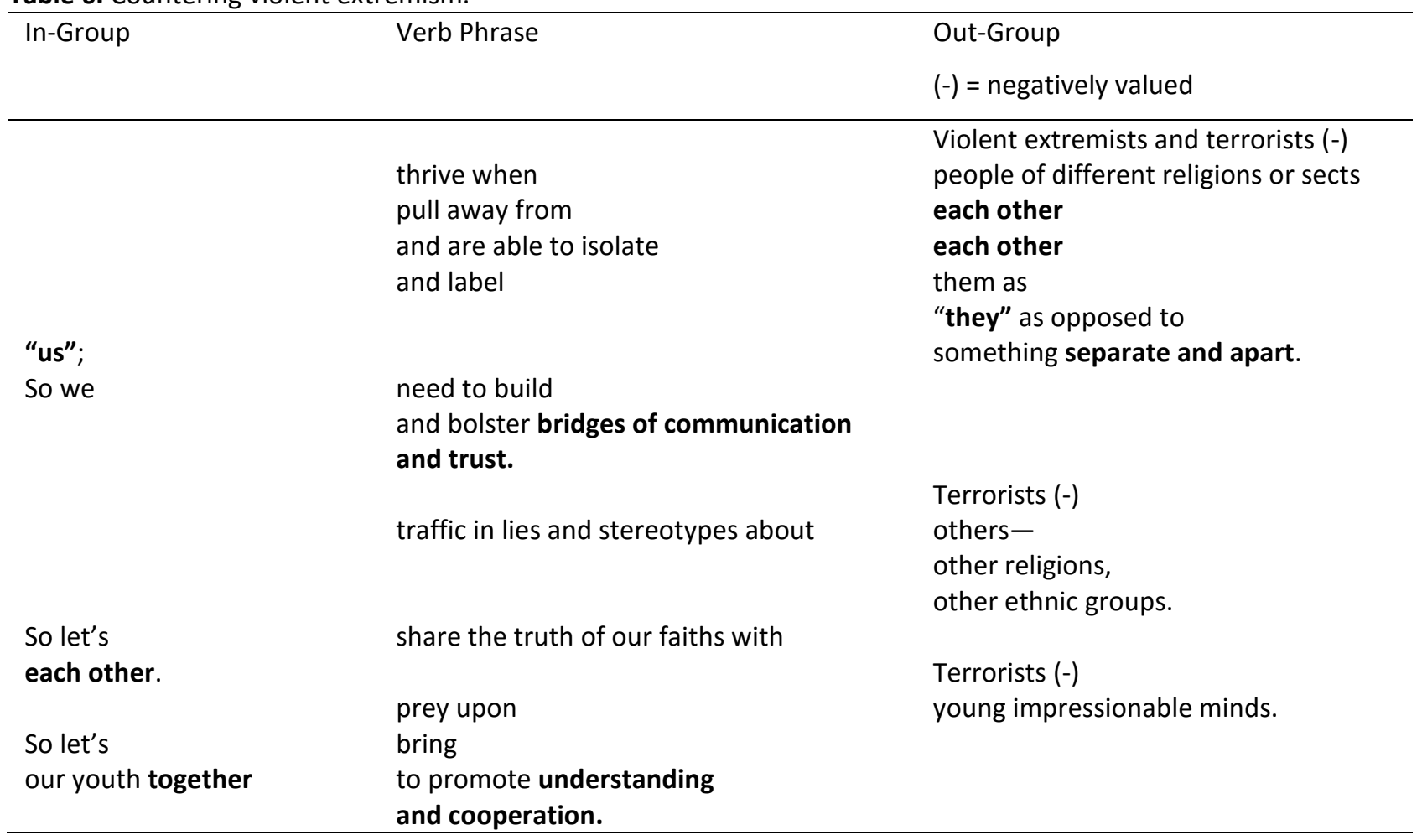


Lest this critique appear too harsh, it is important to acknowledge steps that the Obama administration has taken to advance a more holistic approach to counterterrorism and counterinsurgency. The promotion of initiatives for Countering Violent Extremism (CVE) is one of these steps. Some observers have criticized CVE as amounting to little more than "counterterrorism lite," arguing that outreach efforts to Muslim communities have been hampered by their security-centric orientation (Alliance for Peacebuilding et al., 2015).

But the following passage from President Obama's speech of February 19, 2015 at the Summit on Countering Violent Extremism, diagrammed in Table 6, suggests the potential value of CVE initiatives in helping to soften the cultural divisions between in-groups and out-groups:

Violent extremists and terrorists thrive when people of different religions or sects pull away from each other and are able to isolate each other and label them as "they" as opposed to "us"; something separate and apart. So we need to build and bolster bridges of communication and trust. Terrorists traffic in lies and stereotypes about others -- other religions, other ethnic groups. So let's share the truth of our faiths with each other. Terrorists prey upon young impressionable minds. So let's bring our youth together to promote understanding and cooperation. (Obama, 2015b)

Obama here presents a master class in how to elide rhetorical divisions between "them" and "us." Rather than pulling "away from each other," we must build "bridges of communication and trust." Rather than trafficking in "lies and stereotypes about each other," we must "share the truth of our faiths with each other." Rather than allowing terrorists to "prey upon young impressionable minds," we must "bring our youth together to promote understanding and cooperation."

Though words without action are hollow, the invocation of common ideals and common values can be a critical first step toward healing divisions across cultural, and political, and sectarian lines.

\section{Conclusion: Expanding the In-Group}

In addressing the UN Security Council in September 2013, President Obama identified four "core interests" of the United States in the Middle East and North Africa: to "confront external aggression against our allies and partners," to "ensure the free flow of energy from the region to the world," to "dismantle terrorist networks that threaten our people," and to prevent the "development or use of weapons of mass destruction." He declared that the "United States of America is prepared to use all elements of our power, including mili- tary force," to secure these interests. Obama also alluded to other American interests in the region, such as "to promote democracy and human rights and open markets," in order to help achieve "a Middle East and North Africa that is peaceful and prosperous." Although "we stand ready to do our part to prevent mass atrocities and protect basic human rights," he cautioned, "we cannot and should not bear the burden of acting alone" (Obama, 2013d). In effect, Obama drew a sharp line between the non-negotiable security interests of the United States-e.g. access to energy and the prevention of attacks on the American homelandand those of citizens of the region threatened by war or genocidal regimes.

The deterioration of the international security environment in the Middle East during the two years since Obama's 2013 speech illustrates the shortcomings of this approach, which-whether intentionally or notappeared to elevate the significance of America's "core" security interests above the humanitarian interests of other parties. The stunning rise of the Islamic State was facilitated by systematic assaults on legal and moral order-including mass atrocities in Syria and the breakdown of political and human rights protections for the Sunni minority of Iraq. This essay argues for a more expansive vision of security that acknowledges our moral obligations to others outside the boundaries of our national communities, and that recognizes the connection between U.S. national security and the security of civilians in conflict-affected regions.

Since September 11, 2001, the U.S. government has deployed vast tactical and operational resources to fight terrorist organizations and insurgent movements at the tactical and operational level. It has devoted less systematic attention, however, to developing and implementing a strategy to defeat terrorist organizations at the strategic level. As William Casebeer and James Russell have argued,

A grand counter-terrorism strategy would benefit from a comprehensive consideration of the stories terrorists tell; understanding the narratives which influence the genesis, growth, maturation, and transformation of terrorist organizations will enable us to better fashion a strategy for undermining the efficacy of those narratives so as to deter, disrupt, and defeat terrorist groups. (Casebeer \& Russell, 2005)

Because terrorist organizations are typically far weaker, in terms of their material resources, than the governments against which they are fighting, they seek to find ways to leverage the resources of their opponents to support their own cause. Two common strategies for achieving this objective are what Audrey Kurth Cronin calls provocation and polarization (Cronin, 2012, pp. 195-199; see also Cronin, 2015). 
The provocation strategy involves efforts to encourage one's opponent to overreach-for example by invading Iraq in response to a terrorist attack launched out of Afghanistan-thus depleting its resources and undermining its legitimacy. The polarization strategy attacks the legitimacy of the targeted regime more directly. Through polarization operations, terrorist groups and other insurgencies seek to harden the boundaries between "us" and "them" (the in-group and the outgroup). They achieve this in part by smashing conventional morality and the rule of law in their area of operations, often with the assistance of corrupt, despotic, or incompetent regimes against which they are fighting. Unsurprisingly, terrorist organizations are often strongest in regions with weak or predatory governments (for example, Somalia, Yemen, Northern Mali, Northeastern Nigeria, Eastern Syria, and Western Iraq).

One of the seminal strategic texts cited by ISIL leaders is The Management of Savagery: The Most Critical Stage Through Which the Umma Will Pass, published online by Abu Bakr Naji in 2004. Naji argued that, in order to move Muslims toward "submission to the administration" of the Islamic state, it was first essential to create conditions of "chaos" or "savagery," as a result of which "a spontaneous kind of polarization begins to happen among the people who live in the region of chaos" (Naji, 2004/2006, pp. 27, 110). At this point, he declared:

The people, seeking security, rally around the great personages of the country or a party organization or a jihadi organization or a military organization composed of the remainders of the army or the police of the regimes of apostasy. In this situation, the first step of polarizing these groups begins so that they may enter into mutual professions of loyalty with the people of truth by establishing administrative groups that are subordinate to us in the understanding of how to manage the regions which are under their control, along with undertaking proper media propaganda concerning the situation of our regions with respect to the degree of security, justice by means of implementing the sharia, solidarity, preparation, training, and advancement. We will find (by the permission of God) that along with this first step there will be a continuous emigration of the youth of other regions to our regions in order to assist them and live in them, despite the loss of lives and worldly gains [lit. fruits] or the pressure of the enemies upon these regions. (Naji, 2004/2006, pp. 27, 110-111)

Put more succinctly, a key strategic objective of the Islamic State is the destruction of legal and moral authority in the "region of chaos," to be achieved in part through the commission of mass atrocities, with the goal of hardening the boundaries between the "ingroup" of the pious and the "out-group" of the infidels.
Following Naji's own logic, a comprehensive "counter-narrative strategy" (Casebeer \& Russell, 2005) would aim to achieve the opposite objectives. It would seek to:

1) strengthen the rule of law and human dignity in embattled regions;

2) demonstrate our commitment to shared moral principles and our common humanity by preventing mass atrocities and other attacks on civilians; and

3) "expand the in-group" to include marginalized and oppressed populations, while emphasizing the firm boundary that exists between peaceful expression of legitimate grievances and criminal acts of violence.

In other words, to quote President Obama, an effective global counterterrorism strategy would rest in part on a robust commitment to the principle that "preventing mass atrocities and genocide is a core national security interest and a core moral responsibility of the United States" (Obama, 2011f). In most cases, the fulfillment of this commitment would involve principally nonmilitary rather than military activities. As a coalition of international NGOs declared in a recent joint statement on Countering Violent Extremism, "[A]ny strategy to address today's complex threats [should] focus on supporting communities and states to build safe, just, and resilient societies and addressing the core grievances fueling global radicalization" (Alliance for Peacebuilding et al., 2015).

One of the most perplexing puzzles of the Obama presidency is why an individual so uniquely qualified to "expand the in-group"-the first African American president and perhaps the greatest orator of his generation, born to a father from Kenya and a mother from Kansas, raised in Hawaii and Indonesia-has often chosen to harden the rhetorical boundaries between America and the outside world. In the opening paragraphs of his Nobel Peace Prize acceptance speech of December 2009, Obama saw fit to remind his audience: "I am the Commander-in-Chief of the military of a nation in the midst of two wars" (Obama, 2009b). That same month, addressing the cadets of the U.S. Military Academy at West Point, he depicted America's "overarching goal" in Afghanistan as to "disrupt, dismantle, and defeat al Qaeda in Afghanistan and Pakistan," effectively reducing the security of the Afghan people themselves to an afterthought. "If I did not think that the security of the United States and the safety of the American people were at stake in Afghanistan," he declared, "I would gladly order every single one of our troops home tomorrow" (Obama, 2009a).

This hardening of rhetorical boundaries is evident in many of the speeches that Obama has delivered concerning the crises in Libya, Syria, and Iraq. In discussing 
the plight of the Yezidi, he could have asserted, in the spirit of John F. Kennedy's Berlin address: "We are all Yezidi." Instead, he settled for rhetorical virtuosity that enlisted moral outrage but highlighted the physical and cultural distance between the Yezidi and Americans. In addressing the threat posed by ISIL, he declared that "a core principle of my presidency" was the law of the jungle: "if you threaten America, you will find no safe haven" (Obama, 2014b).

In The Obamians, a portrait of foreign policy decision-making during President Obama first term, James Mann observes that Obama and his closest advisors possessed "a distinctly more modest and downbeat outlook on America's role in the world" than the foreign policy teams of the Clinton and the two Bush administrations (Mann, 2012, p. 71). Obama and his advisors found themselves hemmed in by the constraints of fiscal austerity and the blows to America's confidence and international reputation caused by the global financial crisis of 2008 and the military quagmires in Afghanistan and Iraq. Consequently, "Obama sought to carve out a less assertive role for the United States, one in which it occasionally demonstrated its continuing power and sought to preserve a leadership role in the world, but relied far more on the support of other countries" (Mann, 2012, p. 31).

The present essay is intended as a counterpoint to this "doctrine of restraint," which has served as an implicit organizing principle for President Obama's conduct of foreign policy. Precisely because American military and economic power are increasingly contested and constrained, it is more important than ever for U.S. leaders to engage in robust efforts to craft and communicate a coherent strategic narrative that can enlist cooperation and support from America's friends and international partners. A compelling strategic narrative cannot involve only words; it must involve words that express shared values and that are translated into action. Protecting threatened civilians throughout the world from genocide and mass atrocities is one imperative around which American interests and American values coalesce.

\section{Acknowledgments}

I would like to express my gratitude to Arald Begolli, who did the bulk of the background research for this paper, as well as to Jim Finkel and Anna Samson for their insightful advice and guidance, and to Michael Silverstein for his mentorship and intellectual inspiration. Thanks also to the members of the Washington, DCbased Atrocities Prevention Study Group for their helpful comments on a draft of the essay.

\section{Conflict of Interests}

The author declares no conflict of interests.

\section{References}

Albright, M., \& Cohen, W. (2008). Preventing genocide: A blueprint for U.S. policymakers. Washington, DC: United States Holocaust Memorial Museum, American Academy of Diplomacy, and the United States Institute of Peace. Retrieved from http://media. usip.org/reports/genocide_taskforce_report.pdf

Alliance for Peacebuilding et al. (2015). A U.S. humanitarian, development, and peacebuilding statement on the U.S. global Countering Violent Extremism agenda. July 20. Retrieved from http://www. allianceforpeacebuilding.org/site/wp-content/up loads/2015/07/Statement-FINAL.pdf

Arquilla, J., \& Ronfeldt, D. (Eds.). (2001). Networks and netwars: The future of terror, crime, and militancy. Santa Monica: RAND. Retrieved from www.rand. org/publications/MR/MR1382

Casebeer, W. D., \& Russell, J. A. (2005). Storytelling and terrorism: Towards a comprehensive "counternarrative" strategy. Strategic Insights, 4(3).

Chollet, D., \& Fishman, B. (2015). Who lost Libya? Obama's intervention in retrospect. Foreign Affairs, 94(May/June), 154-157.

Cronin, A. K. (2012). U.S. grand strategy and counterterrorism. Orbis, 56, 192-214.

Cronin, A. K. (2015). ISIS is not a terrorist group. Why counterterrorism won't stop the latest jihadist threat. Foreign Affairs, 94(March/April). Retrieved from https:/www.foreignaffairs.com/articles/ middle-east/2015-02-16/isis-not-terrorist-group

Dorfman, L., Wallack, L., \& Woodruff, K. (2005). More than a message: Framing public health advocacy to change corporate practices. Health Education \& Behavior, 32, 320-336.

Finkel, J. P. (2014). Atrocity prevention at the crossroads: Assessing the President's Atrocity Prevention Board after two years. Center for the Prevention of Genocide Occasional Papers, No. 2. Washington, DC: United States Holocaust Memorial Museum. Retrieved from http://www.ushmm.org/m/pdfs/ 20140904-finkel-atrocity-prevention-report.pdf

Freedman, L. (2006). The transformation of strategic affairs. The International Institute for Strategic Studies, Adelphi Paper 379. London: Routledge.

Goffman, E. (1974). Frame analysis: An essay on the organization of experience. New York: Harper \& Row.

International Crisis Group. (2012). Divided we stand: Libya's enduring conflicts. Middle East/North Africa Report No. 130. September 14. Retrieved from http://www.crisisgroup.org/en/regions/middleeast-north-africa/north-africa/libya/130-dividedwe-stand-libyas-enduring-conflicts.aspx

Jakobson, R. (1960). Closing statement: Linguistics and poetics. In T. A. Sebeok (Ed.), Style in language (pp. 350-377). Cambridge: MIT Press. 
Kahneman, D. (2003). Maps of bounded rationality: Psychology for behavioral economics. The American Economic Review, 93, 1449-1475.

Lakoff, G. P. (1996). Moral politics: What conservatives know that liberals don't. Chicago: University of Chicago Press.

Lakoff, G. P. (2004). Don't think of an elephant: Know your values and frame the debate. White River Junction, Vermont: Chelsea Green Publishing.

Lempert, M., \& Silverstein, M. (2012). Creatures of politics: Media, message, and the American presidency. Bloomington: Indiana University Press.

Levin, P. L., \& Schneider, S. L. (1998). All frames are not created equal: A typology and critical analysis of framing effects. Organizational Behavior and $\mathrm{Hu}$ man Decision Processes, 76, 149-188.

Levinger, M. (1990). La rhétorique protestataire du Parlement de Rouen (1753-1763). AnnalesEconomies, Sociétés, Civilisations, 45, 589-613.

Levinger, M. (2013). Conflict analysis: Understanding causes, unlocking solutions. Washington, DC: United States Institute of Peace Press.

Mann, J. (2012). The Obamians: The struggle inside the White House to redefine American power. New York: Penguin.

Martinez, S. M., Agoglia, J. F., \& Levinger, M. (2013). Effective leadership for a complex world: A developmental approach. In L. Wells II, T.C. Hailes, \& M. C. Davies (Eds.), Changing mindsets to transform security: Leader development for an unpredictable and complex world (pp. 53-80). Washington, DC: National Defense University Center for Technology and National Security Policy.

Naji, A. B. (2004/2006). The management of savagery: The most critical stage through which the umma will pass. Cambridge: John M. Olin Institute for Strategic Studies, Harvard University.

Obama, B. (2004). Transcript of keynote address to the Democratic National Convention. The Washington Post. July 27. Retrieved from http://www.washingto npost.com/wp-dyn/articles/A19751-2004Jul27.html

Obama, B. (2009a). Remarks by the President in address to the nation on the way forward in Afghanistan and Pakistan. December 1. Retrieved from https://www.whitehouse.gov/the-press-office/rem arks-president-address-nation-way-forward-afghan istan-and-pakistan

Obama, B. (2009b). Remarks by the President at the acceptance of the Nobel Peace Prize. December 10. Retrieved from https://www.whitehouse.gov/thepress-office/remarks-president-acceptance-nobelpeace-prize

Obama, B. (2011a). President Obama speaks on the turmoil in Libya: "This violence must stop." February 23. Retrieved from https://www.whitehouse. gov/blog/2011/02/23/president-obama-speaksturmoil-libya-violence-must-stop
Obama, B. (2011b). Remarks by the President on the situation in Libya. March 18. Retrieved from https://www.whitehouse.gov/the-press-

office/2011/03/18/remarks-president-situation-libya

Obama, B. (2011c). Remarks by the President in address to the nation on Libya. March 28. Retrieved from https://www.whitehouse.gov/photosand-video/video/2011/03/28/president-obama-sspeech-libya\#transcript

Obama, B. (2011d). A statement by President Obama on Syria. April 22. Retrieved from https:// www.whitehouse.gov/blog/2011/04/22/statementpresident-obama-syria

Obama, B. (2011e). Remarks by the President on the Middle East and North Africa. May 19. Retrieved from https://www.whitehouse.gov/the-pressoffice/2011/05/19/remarks-president-middle-eastand-north-africa\%20

Obama, B. (2011f). Presidential Study Directive on mass atrocities (PSD 10). August 4. Retrieved from https://www.whitehouse.gov/the-press-office/ 2011/08/04/presidential-study-directive-massatrocities

Obama, B. (2011g). President Obama: "The future of Syria must be determined by its people, but President Bashar al-Assad is standing in their way." August 18. Retrieved from https://www.white house.gov/blog/2011/08/18/president-obamafuture-syria-must-be-determined-its-peoplepresident-bashar-al-assad

Obama, B. (2011h). Remarks by President Obama at United Nations High-Level Meeting on Libya. September 20. Retrieved from https://www.white house.gov/the-press-office/2011/09/20/remarkspresident-obama-high-level-meeting-libya

Obama, B. (2011i). Remarks by President Obama in address to the United Nations General Assembly. September 21. Retrieved from https://www.white house.gov/the-press-office/2011/09/21/remarkspresident-obama-address-united-nations-generalassembly

Obama, B. (2012a). Remarks by the President at the United States Holocaust Memorial Museum. April 23. Retrieved from https://www.whitehouse.gov/ the-press-office/2012/04/23/remarks-presidentunited-states-holocaust-memorial-museum

Obama, B. (2012b). Remarks by the President to the White House Press Corps: Syria red line press conference. August 20. Retrieved from https://www. whitehouse.gov/the-press-office/2012/08/20/ remarks-president-white-house-press-corps

Obama, B. (2012c). Remarks by the President to the UN General Assembly. September 25. Retrieved from https://www.whitehouse.gov/the-pressoffice/2012/09/25/remarks-president-un-generalassembly

Obama, B. (2012d). Remarks by the President at the 
Nunn-Lugar Cooperative Threat Reduction Symposium. December 3. Retrieved from https:// www.whitehouse.gov/the-press-office/2012/12/ 03/remarks-president-nunn-lugar-cooperativethreat-reduction-symposium

Obama, B. (2013a). Statement by the President on Syria. August 31. Retrieved from https://www. whitehouse.gov/the-press-office/2013/08/31/state ment-president-syria

Obama, B. (2013b). Weekly address: Calling for limited military action in Syria. September 7. Retrieved from https://www.whitehouse.gov/the-pressoffice/2013/09/07/weekly-address-calling-limitedmilitary-action-syria

Obama, B. (2013c). Remarks by the President in address to the nation on Syria. September 10. Retrieved from https://www.whitehouse.gov/thepress-office/2013/09/10/remarks-presidentaddress-nation-syria

Obama, B. (2013d). Remarks by President Obama in address to the United Nations General Assembly. September 24. Retrieved from https://www. whitehouse.gov/the-press-office/2013/09/24/ remarks-president-obama-address-united-nationsgeneral-assembly

Obama, B. (2014a). Statement by the President. August 8. Retrieved from https://www.whitehouse.gov/ photos-and-video/video/2014/08/07/presidentobama-makes-statement-iraq\#transcript

Obama, B. (2014b). Statement by the President on ISIL. September 10. Retrieved from https://www. whitehouse.gov/the-press-office/2014/09/10/ statement-president-isil-1

Obama, B. (2014c). Statement by the President on airstrikes in Syria. September 23. Retrieved from https://www.whitehouse.gov/the-pressoffice/2014/09/23/statement-president-airstrikessyria
Obama, B. (2015a). Remarks by the President on request to Congress for authorization of force against ISIL. February 11. Retrieved from https://www. whitehouse.gov/the-press-office/2015/02/11/ remarks-president-request-congress-authorizationforce-against-isil

Obama, B. (2015b). Remarks by the President at the Summit on Countering Violent Extremism. February 19. Retrieved from https://www.whitehouse.gov/ the-press-office/2015/02/19/remarks-presidentsummit-countering-violent-extremism-february-192015

Power, S. (2003). "A problem from hell": America and the age of genocide. New York: HarperCollins.

Scheufele, D. A. (1999). Framing as a theory of media effects. Journal of Communication, 49, 103-122.

Tversky, A., \& Kahneman, D. (1981). The framing of decisions and the psychology of choice. Science 211(4481), 453-458.

United States Agency for International Development (USAID). (2015). Field guide: Helping prevent mass atrocities. Washington, DC: USAID.

United States Department of Defense (DOD). (2012). Joint publication 3-07.3: Peace operations. Washington, DC: DOD. Retrieved from http://fas.org/ irp/doddir/dod/jp3-07-3.pdf

United States Department of State. (2015). Quadrennial Diplomacy and Development Review: Enduring leadership in a dynamic world. Washington, DC: United States Department of State. Retrieved from http://www.state.gov/documents/organization/24 1429.pdf

Weiss, M. (2014). The unraveling: How Obama's Syria policy fell apart. Politico Magazine. January 2. Retrieved from http://www.politico.com/magazine/ story/2014/01/how-obamas-syria-policy-fell-apart101704_Page3.html\#.VVSG-NpViko

\section{About the Author}

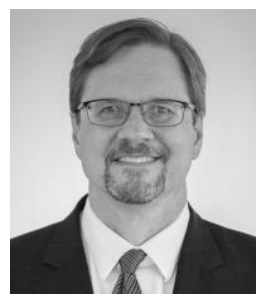

\section{Dr. Matthew Levinger}

Matthew Levinger is Research Professor of International Affairs at the George Washington University. He directs the National Security Studies Program, an executive education program for senior officials from the U.S. government and its international partners, as well as the Master of International Policy and Practice Program. He served previously as Founding Director of the Academy for Genocide Prevention at the United States Holocaust Memorial Museum and as Senior Program Officer at the United States Institute of Peace. He received his Ph.D. in History from the University of Chicago. 